KOLOM ILMIAH

Science and Technology

\title{
TINJAUAN HUBUNGAN KUAT TEKAN DAN LENTUR BETON DENGAN BAHAN TAMBAH SERAT BAJA UNTUK PERKERASAN PAKU
}

\author{
Hermansyah ${ }^{1}$, Muhammad Fauzie Siswanto ${ }^{2}$, Ashar Saputra ${ }^{3}$ \\ 1,2Magister Sistem dan Teknik Transportasi /Fakultas Teknik, UGM \\ ${ }^{3}$ Magister Sarana Prasarana dan Teknologi Bahan/Departemen Teknik sipil dan Lingkungan/ \\ Fakultas Teknik, UGM \\ Email: hermansyah111090@gmail.com, fauzie.siswanto@ugm.ac.id, ashar@tsipil.ugm.ac.id
}

\begin{tabular}{|c|c|}
\hline \multicolumn{2}{|r|}{ ABSTRACT } \\
\hline $\begin{array}{l}\text { Diterima: } \\
\text { Januari } 2019\end{array}$ & $\begin{array}{l}\text { The Director General of Highways issued the } 2010 \text { revision } 3 \text { specification concerning } \\
\text { minimum flexural strength for rigid pavement of } 45 \mathrm{~kg} / \mathrm{cm} 2 \text { or approximately } 4.5 \mathrm{MPa} \text {, } \\
\text { but the reality of obtaining such flexural strength should be using high enough } \\
\text { concrete quality and it will incur considerably high cost also. In this study was using a }\end{array}$ \\
\hline $\begin{array}{l}\text { Diterbitkan: } \\
\text { Februari } 2019\end{array}$ & $\begin{array}{l}\text { normal concrete method with the purpose of research to know the relationship of } \\
\text { compressive strength and flexural of concrete with the addition of variation of fiber } 0 \% \text {, } \\
0,5 \%, 0,65 \% \text { and } 0,8 \% \text { from weight of the concrete mixture. The results from this } \\
\text { research showed that the compressive strength and flexure had increased }\end{array}$ \\
\hline $\begin{array}{l}\text { Keywords: } \\
\text { compressive } \\
\text { strength, } \\
\text { flexural } \\
\text { strength, steel } \\
\text { fiber }\end{array}$ & $\begin{array}{l}\text { successively in the fiber variation } 0 \%, 0.5 \% \text { and } 0.65 \% \text { amount } 31.23 \mathrm{MPa}, 33.06 \\
\mathrm{MPa}, 35.23 \mathrm{MPa} \text { and } 4.58 \mathrm{MPa}, 4.75 \mathrm{MPa}, 5.04 \mathrm{MPa} \text {. It is because the fiber } \\
\text { contained in the concrete has a fairly even distribution of fiber and does not have } \\
\text { clumping. When variations of fiber above } 0.65 \% \text { such as } 0.8 \% \text { variation in the } \\
\text { direction of fiber are difficult to control and at the time of mixing occurs clumping, So } \\
\text { the value of compressive strength and flexural of concrete are decreases. The relation } \\
\text { of compressive strength and flexural of concrete using a variation of steel fiber to } \\
\text { obtain equation fs }=0,1226 . \mathrm{fc} \text { ' }+0,7173 \text { with value } \mathrm{R}^{2}=0,9915 \text { and } \alpha 0,82 \text {. The } \\
\text { results obtained from the test is a rather good when compared with } \mathrm{ACl} \text { and SNI T- } \\
15-1991-03 \text { method. }\end{array}$ \\
\hline
\end{tabular}

\section{PENDAHULUAN}

Semakin majunya peradaban, kebutuhan masyarakatpun disuatu daerah semakin lama semakin meningkat, seperti pembangunan mall, perkantoran, dan tempat wisata, sehingga dapat menarik perjalan yang sangat tinggi, itu mengakibatkan volume kendaraan menjadi semakin meningkat. Dengan meningkatnya jumlah perjalanan atau volume kendaraan, maka dapat dimungkinkan beban muatan jalanpun semakin meningkat, sehingga pada saat perencanaan harus jeli dalam memilih jenis perkerasan apa yang baik untuk digunakan dengan beban kendaraan rencana sesuai dengan muatan sumbu terberat. Salah satu perkerasan yang digunakan untuk menangani beban rencana yang cukup berat yaitu perkerasan kaku.

Perkerasan kaku memiliki kuat tekan yang cukup baik, namun bertolak belakang dengan kuat lentur, itu dikarenakan sifat yang getas, sehingga pada perencanaan perkerasan kaku menambahkan serat pada campuran beton dengan harapan menambah sifat elastis atau kelenturan dari perkerasan kaku itu sendiri. Bahan tambah serat harus memiliki nilai modulus elastisitas lebih tinggi dari modulus elastisitas beton, dan ini berlaku pada serat alami maupun buatan. Spesifikasi 2010 revisi 3 devisi 5 tentang perkerasan jalan beton semen menjelaskan kuat lentur minimum untuk untuk perkerasan kaku sebesar $45 \mathrm{~kg} / \mathrm{cm} 2$, namun untuk mencapai kuat lentur minimum tersebut perlu menggunakan kuat tekan beton mutu tinggi dan itu cukup memberatkan untuk penyedia jasa, sehingga butuh dilakukan kajian mendalam untuk menghasilkan kuat lentur yang tinggi namun dengan menggunakan mutu beton normal.

Tujuan dari penelitian ini adalah untuk mengetahui pengaruh penambahan variasi serat $0 \%, 0,5 \%, 0,65 \%$ dan $0,8 \%$ dari berat volume campuran beton terhadap kuat tekan dan kuat lentur serta untuk mengetahui hubungan keduanya. 


\section{LANDASAN TEORI}

(Tjokrodimuljo, 2007) Kuat tekan beton adalah perbandingan beban terhadap luas penampang beton.

$$
f^{\prime} c^{\prime}=\frac{P}{A}
$$

keterangan :

$$
\begin{array}{ll}
\mathrm{fc}^{\prime} & =\text { kuat tekan beton }(\mathrm{MPa}) \\
\mathrm{P} & =\text { beban tekan }(\mathrm{N}) \\
\mathrm{A} & =\text { luas penampang }(\mathrm{mm} 2)
\end{array}
$$

Kuat lentur merupakan dimana kemampuan benda uji beton yang berbentuk balok yang diletakkan pada dua perletakan dengan tujuan menahan gaya yang arah gayanya tegak lurus sumbu benda uji, sehingga benda uji mengalami patah yang dinyatakan dalam mega pascal (MPa) gaya setiap satuan luas.

$$
f_{S}=\frac{P . a}{b \cdot h 2}
$$

keterangan :

$$
\begin{array}{ll}
\mathrm{fs} & =\text { kuat lentur }(\mathrm{MPa}) \\
\mathrm{P} & =\text { beban tekan }(\mathrm{N}) \\
\mathrm{a} & =\text { jarak perletakan ke gaya }(\mathrm{mm}) \\
\mathrm{b} & =\text { lebar penampang balok }(\mathrm{mm}) \\
\mathrm{h} & \quad=\text { tinggi penampang balok }(\mathrm{mm})
\end{array}
$$

Spesifikasi 2010 revisi 3 menjelaskan kuat lentur minimum untuk perkerasan kaku umur 28 hari sebesar $45 \mathrm{~kg} / \mathrm{cm} 2$. Untuk menghasilkan nilai kuat lentur $45 \mathrm{~kg} / \mathrm{cm} 2$ harus menggunakan mutu

Dari hasil perhitungan $\mathrm{m} 3$ di atas, maka didapatkan nilai campuran dari setiap variasi, untuk lebih jelas dapat dilihat pada tabel 2 .

Tabel 2 Campuran beton untuk setiap variasi serat percampuran

\begin{tabular}{llllll}
\hline Variasi (\%) & A.Kasar $(\mathrm{Kg})$ & A.Halus $(\mathrm{Kg})$ & Semen $(\mathrm{Kg})$ & Air $(\mathrm{Kg})$ & Serat $(\mathrm{Kg})$ \\
\hline 0,00 & 216,46 & 127,13 & 73,35 & 36,68 & 0,0 \\
0,50 & 216,46 & 127,13 & 73,35 & 36,68 & 2,3 \\
0,65 & 216,46 & 127,13 & 73,35 & 36,68 & 3,0 \\
0,80 & 216,46 & 127,13 & 73,35 & 36,68 & 3,7 \\
\hline
\end{tabular}

Pengujian nilai slump

Pada campuran di atas menghasilkan nilai slump sebagai berikut: beton tinggi dan itu dianggap cukup berat dalam hal biaya.

\section{METODOLOGI}

Bahan-bahan dasar beton yaitu semen PPC merek Gresik, air, pasir, batu pecah $20 \mathrm{~mm}$ dengan nilai abrasi $38 \%$ dan juga bahan tambah serat baja bermerek Dramix 3D 65/35 BG. Selain bahan, alat pencetakan yang digunakan adalah balok berukuran $150 \mathrm{~mm} \times 150 \mathrm{~mm} \times 510 \mathrm{~mm}$ sebanyak 5 buah pervariasi, serta silinder berukuran $150 \mathrm{~mm} \times 300$ mm sebanyak 3 buah pervariasi.

Pengujian kuat tekan dan lentur dilakukan untuk mengetahui kemampuan beton yang dihasilkan dalam menerima beban pada pengujian umur 28 hari. Setelah didapatkan hasil penelitian, selanjutnya data tersebut diolah dan dianalisis nilai kuat tekan, kuat lentur dan hubungan kuat tekan dengan lentur beton dengan menggunakan bahan tambah serat baja. Pada pengumpulan data yang akan dianalisis mengabil nilai rata-rata dari setiap variasi baik untuk kuat tekan maupun kuat lentur.

\section{HASIL DAN PEMBAHASAN}

Dalam perencanaan campuran beton dengan menggunakan metode SNI 03-2834-2000, maka didapatkan hasil sebagai berikut:

Tabel 1 Campuran beton untuk $1 \mathrm{~m}^{3}$

\begin{tabular}{llll}
\hline No & Uraian & Nilai / Jenis & Satuan \\
\hline 1 & Nilai Kadar Air Bebas & 190 & $\mathrm{~kg} / \mathrm{m}^{3}$ \\
2 & Jumlah Semen & 380 & $\mathrm{~kg} / \mathrm{m}^{3}$ \\
3 & Kadar Agregat Halus & 658.6 & $\mathrm{~kg} / \mathrm{m}^{3}$ \\
4 & Kadar Agregat Kasar & 1121.4 & $\mathrm{~kg} / \mathrm{m}^{3}$ \\
\hline \multicolumn{2}{l}{ Total } & 2350 & $\mathrm{~kg} / \mathrm{m}^{3}$ \\
\hline
\end{tabular}


IURNAL TAMBORA

Vol. 3 No. 1 Februari 2019

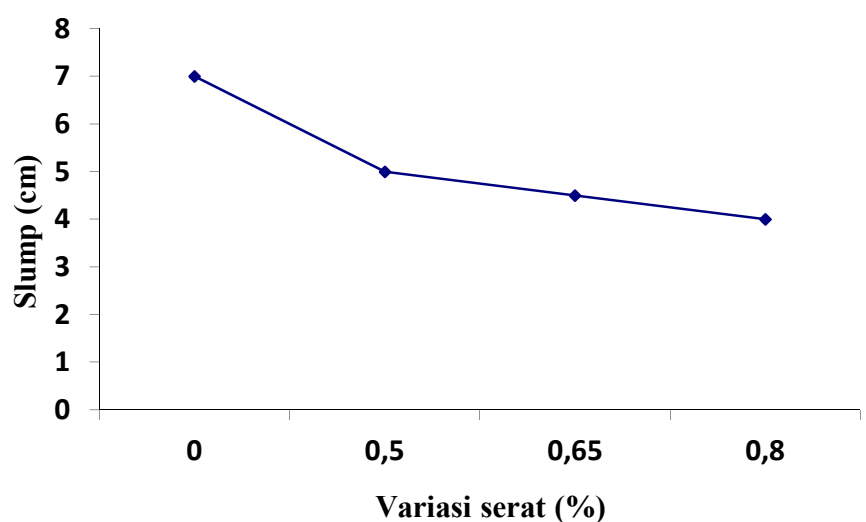

Gambar 1 Hubungan nilai slump dengan variasi serat

Pada pengerjaan campuran beton antara $0 \%$ serat dengan serat $0,5 \%, 0,65 \%$ dan $0,8 \%$ tidak terlalu signifikan dari segi kelecakan, karena nilai FAS dan slump pada setiap campuran beton direncanakan sama. Hasil pengujian pada nilai slump dengan variasi serat baja mendapatkan hasil bahwa semakin banyak penambahan serat pada campuran beton, maka menghasilkan nilai slump yang semakin kecil. Hasilnya dapat dibuktikan pada gambar 1 nilai slump yang semakin kecil tersebut disebabkan oleh serat yang saling mengikat satu sama lain, sehingga keruntuhan yang terjadi cukup kecil.

Pengujian berat volume

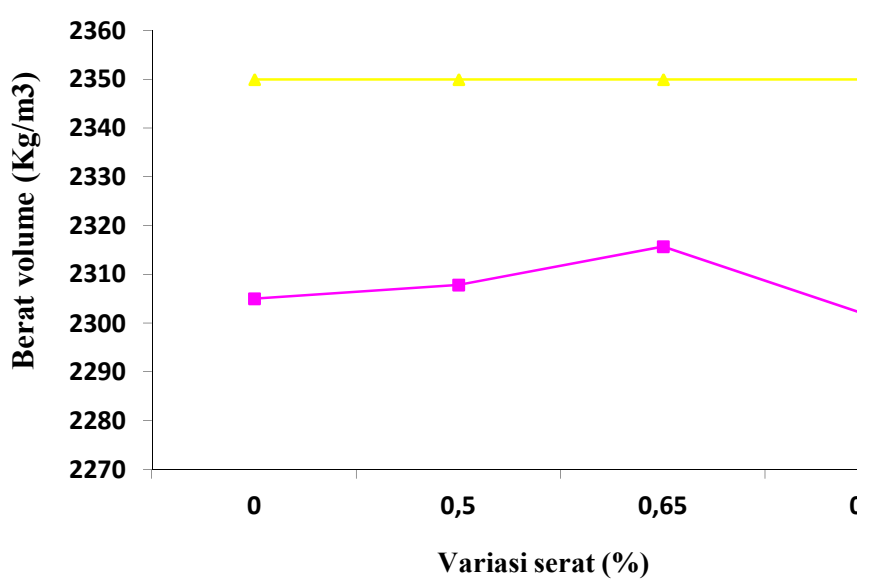

Gambar 2 Hubungan berat volume dengan variasi serat

Dari hasil pencampuran beton dengan variasi serat baja yang ditampilkan oleh gambar 2 menjelaskan bahwa pada umur 28 hari berat volume tertinggi terdapat pada variasi serat $0,65 \%$ sebesar $2315,71 \mathrm{~kg} / \mathrm{m} 3$. Bila dibandingkan dengan berat volume rencana sebesar $2350 \mathrm{~kg} / \mathrm{m} 3$ maka pada varisi $0 \%, \quad 0,5 \%, \quad 0,65 \%$ dan $0,8 \%$ menghasilkan nilai sebesar 1,91\%, 1,79\%, 1,46\% dan $2,05 \%$ pada umur 28 hari. Berat volume yang semakin meningkat dari variasi $0 \%, 0,5 \%$ dan $0,65 \%$ dikarenakan penambahan serat pada campuran beton yang semakin baertambah, namun pada serat $0,8 \%$ mengalami penurunan berat volume yang diakibatkan penggumpalan serat pada campuran beton sehingga pada saat pemadatan agregat kasar sulit mengisi tiap rongga karena terhalang oleh serat.

Pengujian kuat tekan

Tabel 3 Hubungan kuat tekan dan variasi serat baja

\begin{tabular}{lllll}
\hline Variasi (\%) & 0 & 0.5 & 0.65 & 0.8 \\
\hline 28 hari & 31.23 & 33.06 & 35.23 & 30.11 \\
\hline
\end{tabular}

Pada tabel.3 menjelaskan nilai kuat tekan tertinggi dapat pada variasi serat $0,65 \%$ sebesar 35,23 MPa. Hubungan kuat tekan dan variasi serat juga disajikan dalam bentuk gambar 3 .

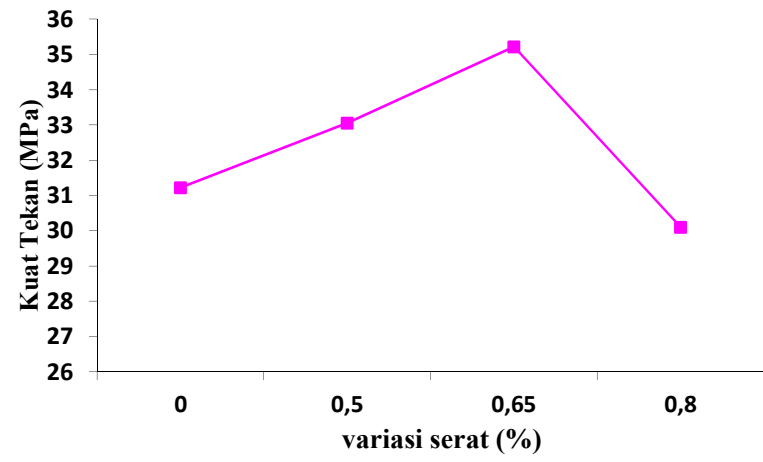

Gambar 3 Hubungan kuat tekan dengan variasi serat

Pada pengujian umur 28 hari terlihat bahwa kuat tekan mengalami peningkatan secara berturutturut dari variasi serat $0 \%, 0,5 \%$ dan $0,65 \%$, yaitu sebesar 31,23 $\mathrm{MPa}, 33,06 \mathrm{MPa}$ dan 35,23 $\mathrm{MPa}$. Peningkatan ini disebabkan oleh serat yang ditambahkan dalam beton tidak mengalami penggumpalan secara berarti sehinnga serat dapat memberikan kekuatan yang cukup baik dengan menunda regangan pada beton secara cepat.

Penambahan serat di atas $0,65 \%$ seperti pada variasi $0,8 \%$ akan mengakibatkan penurunan nilai kuat tekan pada umur 28 hari, ini disebabkan oleh mulainya penggumpalan serat pada campuran yang menghasilkan rongga pada beton cukup banyak, ini dimungkinkan nilai pengujian kuat tekan akan menjadi menurun, sehinnga penambahan serat $0,8 \%$ tidak dianjurkan dalam perencanaan campuran perkerasan kaku.

Pengujian kuat lentur

Tabel 4 Hubungan kuat lentur dan variasi serat

\begin{tabular}{lllll}
\multicolumn{5}{c}{ baja } \\
\hline Variasi (\%) & 0 & 0.5 & 0.65 & 0.8 \\
\hline 28 hari & 4.58 & 4.75 & 5.04 & 4.39
\end{tabular}

Pada tabel.4 menampilkan hasil kuat lentur tertinggi dari hubungan kuat lentur dan variasi serat terdapat pada variasi $0,65 \%$ sebesar 5,04 $\mathrm{MPa}$. 
JURNAL TAMBORA

Vol. 3 No. 1 Februari 2019

Untuk memperjelas pembacaan data maka data ditampilkan dalam bentuk gambar 4 .

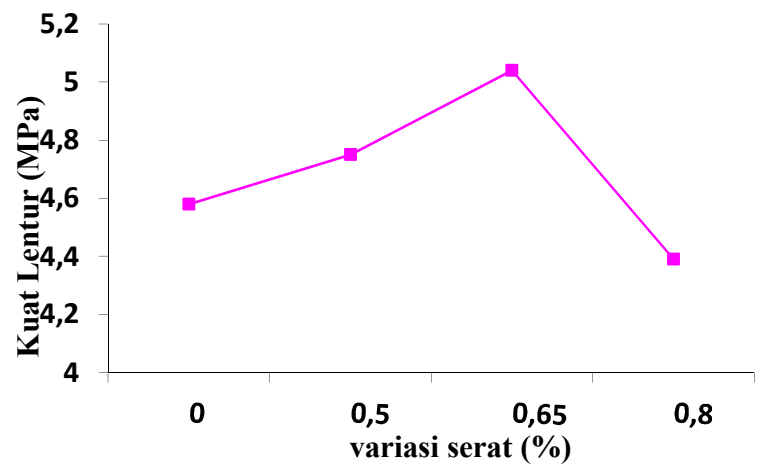

Gambar 4 hubungan kuat tekan dengan variasi serat

Pada pengujian umur 28 hari kuat lentur beton mengalami peningkatan yang secara berturut-turut dari variasi $0 \%, 0,5 \%$ dan $0,65 \%$ sebesar $4,58 \mathrm{MPa}$, 4,75 $\mathrm{MPa}$ dan 5,04 $\mathrm{MPa}$. Peningkatan nilai kuat lentur tersebut diakibatkan oleh arah serat yang seragam (horizontal) berlawan arah dengan titik pusat beban sehingga saat pengujian dilakukan serat dapat menunda terjadinya keretakan seiring dengan bertambahnya beban. Selanjutnya bila dilihat pada variasi serat $0,8 \%$ mengalami penurunan kuat lentur, ini diakibatkan oleh arah serat yang sulit dikontrol karena mengalami penggumpalan.

Pada pengujian kuat lentur untuk variasi $0 \%$ sebenarnya telah memenuhi syarat spesifikasi nilai kuat lentur minimum Spesifikasi 2010 revisi 3 devisi 5 tentang perkerasan jalan beton semen, kemungkinan hasil nilai kuat lentur yang cukup tinggi pada variasi $0 \%$ dipengaruhi oleh penggunaan semen PPC (Portland Pozzolan Cement).

Pengujian hubungan kuat tekan dengan lentur beton

Tabel 5 Perbandingan hubungan kuat tekan dan lentur beton

\begin{tabular}{llllll}
\hline $\begin{array}{l}\text { Variasi } \\
(\%)\end{array}$ & $\begin{array}{l}\mathrm{fc}^{\prime} \\
(\mathrm{MPa})\end{array}$ & $\begin{array}{l}\sqrt{\mathrm{fc}^{\prime}} \\
(\mathrm{MPa})\end{array}$ & $\begin{array}{l}\mathrm{fs} \\
(\mathrm{MPa})\end{array}$ & $\begin{array}{l}\mathrm{S} \\
\mathrm{NI}\end{array}$ & $\begin{array}{l}\mathrm{A} \\
\mathrm{CI}\end{array}$ \\
\hline 0 & 31.23 & 5.59 & 4.58 & $\begin{array}{l}3.9 \\
1\end{array}$ & $\begin{array}{l}3.4 \\
6\end{array}$ \\
0,5 & 33.06 & 5.75 & 4.75 & $\begin{array}{l}4.0 \\
2\end{array}$ & $\begin{array}{l}3.5 \\
6\end{array}$ \\
0,65 & 35.23 & 5.94 & 5.04 & 4.1 & 3.6 \\
0,8 & 30.11 & 5.49 & 4.39 & 3.8 & 8.4 \\
\hline
\end{tabular}

\section{PENUTUP}

\section{Kesimpulan}

Dari hasil penelitian yang dilakukan maka dapat ditarik kesimpulan bahwa pada hasil pengujian kuat tekan beton untuk nilai tertinggi dengan variasi serat baja pada umur 28 hari terdapat pada variasi serat $0,65 \%$ sebesar $35,23 \mathrm{MPa}$. Pengujian kuat lentur beton untuk nilai tertinggi dengan variasi serat baja pada umur 28 hari terdapat pada variasi
Pada tabel 5 menjelaskan bahwa hubunga kuat tekan dan lentur beton dari hasil pengujian, dibandingkan dengan metode yang dikeluarkan oleh SNI T-15-1991-03 dan ACI (American Concrete Institute). perbandingan juga disajikan dalam bentuk Gambar.7.

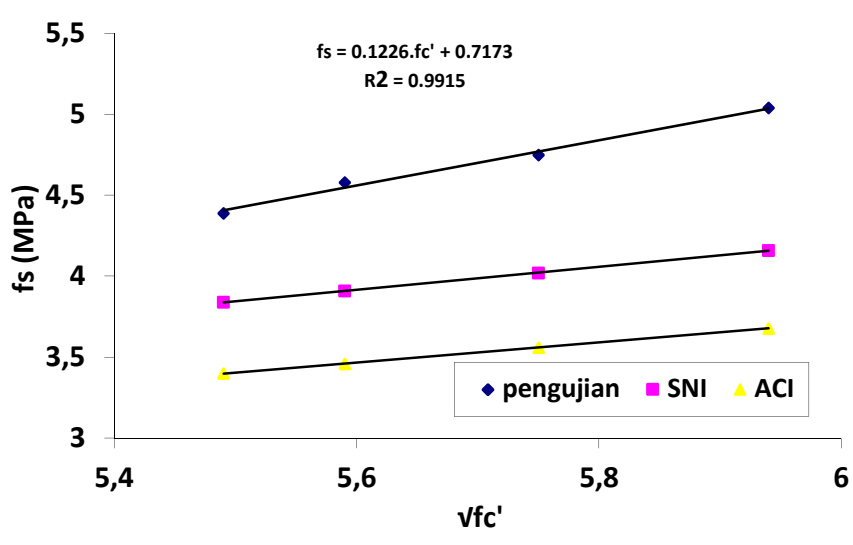

Gambar 5 Hubungan kuat tekan dengan lentur beton

Persamaan hubungan kuat tekan dengan lentur yaitu $\mathrm{y}=0,1226 . \mathrm{fc}^{\prime}+0,7173$ dengan nilai $\mathrm{R} 2=$ 0,9915 dan nilai $\alpha$ rata-rata $=0,81$. Dari hasil tersebut lebih baik bila dibandingkan dengan metode ACI (American Concrete Institute) dan SNI T-15-1991-03 yaitu fr $=0,62 . \sqrt{ } \mathrm{fc}^{\prime}$ dan $\mathrm{fr}=$ $0,70 . \sqrt{ } \mathrm{fc}$ ', ini dibuktikan pada Gambar 5 nilai hasil pengujian memiliki nilai fs yang lebih tinggi dari metode ACI (American Concrete Institute) dan SNI T-15-1991-03.

Peningkatan nilai $\alpha$ pada hubungan kuat tekan dan lentur beton diakibatkan oleh hasil dari pengujian telah memenuhi syarat dari perencanaan awal, sehingga pada saat mencari nilai kuat lentur dengan persamaan tersebut, nilai $\alpha$ mengalami peningkatan yang cukup signifikan.

serat $0,65 \%$ sebesar 5,04 $\mathrm{MPa}$. namun dengan variasi $0 \%$ pada penelitian ini sebenarnya telah memenuhi syarat nilai kuat lentur minimum 4,5 MPa yang dikeluarkan oleh spesifikasi 2010 revisi 3 devisi 5 tentang perkerasan berbutir dan perkerasan beton semen dengan nilai hasil kuat lentur sebesar 4,58 $\mathrm{MPa}$. Dari hasil hubungan kuat tekan dan lentur beton dengan menggunakan variasi serat baja menghasilkan persamaan fs $=$ 0,1226 .fc' $+0,7173$ dengan nilai $\mathrm{R} 2=0,9915$ dan $\alpha$ 
rata-rata $=0,81$. Hasil yang diperoleh lebih baik dari metode ACI dan SNI T-15-1991-03, sehingga dapat digunakan sebagai alternatif untuk perencanaan perkerasan kaku untuk kedepannya.

\section{UCAPAN TERIMA KASIH}

Pada kesempatan ini penulis mengucapkan terima kasih kepada Bapak Dr.Ir.Muhammad Fauzie Siswanto.M.Sc dan Bapak Ashar Saputra.S.T.,M.T.,Ph.D yang selalu memberikan saran dan masukan pada penulis agar penelitian ini dapat berjalan dengan lancar.

\section{REFERENSI}

ACI Committee 363R-92, (1997). State-of-the-Art Report on High-Strength Concrete

Dirjen Bina Marga, Kementrian Pekerjaan Umum, (2010). Spesifikasi 2010 (Revisi 3) Divisi 5 Perkerasan Berbutir dan Perkerasan Beton Semen, Puslitbang Jalan dan Jembatan, Bandung
Murdock dan Brook, (1986). Bahan dan Praktek Beton Edisi Keempat, Penerbit Erlangga, Jakarta.

SK SNI T-15-1990-03, (1990). Tata Cara Pembuatan Rencana Campuran Beton Normal, Yayasan LPMB, Bandung.

SNI 03-2834-2000, (2000). Tata Cara Pembuatan Rencana Campuran Beton Normal, Pusjatan-Balitbang PU, Bandung

Sukismo, (2017). Penelitian Studi Eksperimental Pengaruh Penggunanan Stell Fiber Terhadap Uji Kuat Tekan, Tarik Belah dan Kuat tarik lentur Pada Campuran Beton Mutu Fc' 25 Mpa, Untan, Pontianak.

Tjokrodimulyo (2007). Teknologi Beton, Biro Penerbit, Yogyakarta

Wirawan, B, (2016). Analisis Petrografi Agregat Terhadap Kuat Tekan Dan Kuat tarik lentur Beton Perkerasan Kaku. Fakultas Teknik Sipil Fakultas Teknik Universitas Sebelas Maret, Surakarta. 